\section{EXPERIENCES WITH MOODLE AS A COMMUNICATION TOOL FOR DESIGN TEAMWORK: A USERS' PERSPECTIVE}

\author{
Şule TAŞLI PEKTAŞ, Halime DEMİKAN
}

Received: 10.04.2011, Final Text: 13.08.2011

Keywords: collaborative design; design education; MOODLE; usability; users' perception.

\section{INTRODUCTION}

With the rapid increase of technology every educational institution has the opportunity to make use of the Internet as a communication medium for instruction. This facility makes education independent of time and location and supports the students in an environment that can design in a team as active, independent, self-reflected and collaborative participants. Moreover, web-based design education enables flexibility for time and place constraints in collaborative teaching and learning (Sagun and Demirkan, 2009). However, it was observed that most of the existing studies on the utilization of Web-based tools in design education adopted a developer's and/or an instructor's viewpoint, while, users' needs, perceptions, and experiences were rarely explored (Karakaya and Pektaş, 2007).

In this study, the usability of a Learning Management System named MOODLE (Modular Object-Oriented Dynamic Learning Environment) that offers a wide range of functionalities to support design collaboration is analyzed. MOODLE provides many features for supporting design collaboration, from simple document sharing to on-line design critiques. Furthermore in design process, this collaboration environment can be driven by the success of platforms such as Active Worlds (Dede et al. 2003) or Second Life (De Lucia et al. 2009; Livingstone and Kemp, 2008).

A learning management system like MOODLE allows students to communicate with instructors and team members, give and take online critiques, download course materials, design briefs, submit design sketches and design projects. The utilization of MOODLE for design communication purposes seems quite appropriate, since the main premise underlying a course management system like MOODLE is learning through interaction. The design and development of MOODLE is guided by "social constructionist pedagogy". According to this view, learners actively "construct" new knowledge as they interact with others in social settings wherein groups collaboratively creating a culture of shared 
artifacts with shared meanings (MOODLE-DOCS, 2010). Although this is a very powerful theoretical proposition, it is observed that most of the existing studies focused on the advantages of course management systems as repositories of course information (Yuen et al., 2008; Martens and Achten, 2007; Hoog, Falkner and Seifried, 2007). Studies on the use of course management systems for design teamwork are rare. Hamuy and Galaz (2010) criticized such approaches and claimed that more efforts should be devoted to communication aspects in course management system applications. Similarly, Reichl and Hruska (2009) discussed that encouraging the use of a course management system as a multi-purpose tool to support all kinds of collaboration and communication activities besides the regular teaching activities had led to a rapid and significant increase in user numbers and encouraged university instructors to deal with educational questions and to develop innovative learning and teaching solutions based on the course management system. Novakova, Achten and Matejovska (2010) used MOODLE in design studio teaching, but they did not report about the usability of the tool. Thus, the paper aims to alleviate a research gap in this area in design education.

Within this framework, the study discusses the students' perception of MOODLE as a communication tool for design teamwork. In the research setting, a sample of interior architecture students that were grouped in teams, engaged with a domain-specific design task in which MOODLE was used as the main communication tool. Then, the perceptions of the subjects about the process were evaluated through an empirical survey.

The particular research questions of the study are presented below:

1. What are the factors that are especially important in terms of the perceived usefulness and perceived ease of use of MOODLE as a communication tool for teamwork in design education?

2. What are the users' perceptions while using MOODLE as a communication tool for design teamwork in relation to the defined factors?

3. What are the relationships between individual differences of learners (gender, computer experience, and computer self-efficacy) and perception of MOODLE as a communication tool for design teamwork?

In sum, this study aims to apply MOODLE (an established and widely used course management system in many fields) as a communication tool in design teamwork and to understand the usability of the tool. To the best of the authors' knowledge, this study is the first to investigate these issues.

\section{MOODLE}

MOODLE is an open-source virtual learning environment and a course management system that is used for educational purposes in many different disciplines (MOODLE, 2010). Bilkent University integrated MOODLE to the university's course registration system in 2007 and the tool is widely used in hybrid/blended courses (i.e. courses conducted both with online and traditional education techniques) in the university.

MOODLE offers a structured interface to its users. After accessing to the MOODLE, a screen that contains a presentation of the system, an overview of available courses, together with a series of useful links is observed. 


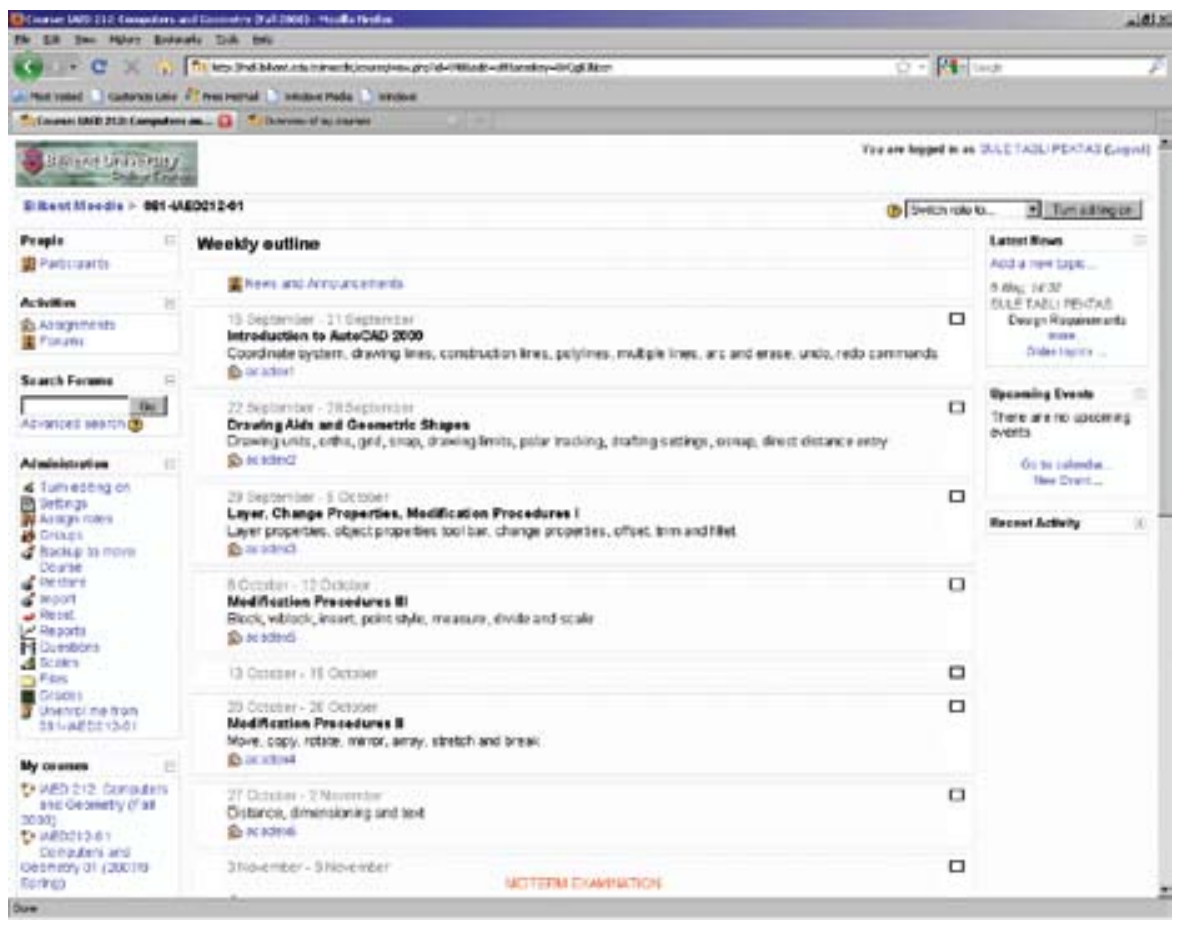

A student then accesses to the chosen course by selecting it from the list provided. Once a student has selected a course, its main page is displayed. The page is divided into three columns. The left column is composed by links leading to pages dedicated to the participation of the course. People, Activities, and Administration are the main headings: People gives information about the participants, Activities involves the Assignments and Forums, and Administration involves some buttons to manage the personal settings. The central column is dedicated to the format of the course in a specified time unit as weekly and enlists the resources and activities composing them. Finally, the right part of the window displays information about latest events as news posted by the teacher, changes in the Activities and on-line users (Figure 1).

From the course page, students have access to all the material comprising the course. Activities can be selected either from the central column related to the specific time unit or from the link in the left column. MOODLE also allows instructors to divide their classes in different Groups, whose students can design their projects separately and provides its users with a list of the Participants of the course. In order to inform students and instructors of new messages, the tool sends an e-mail that contains a notice about a new entry and a link to MOODLE. Forum posts can include attachments and images that can be formatted. Student users of MOODLE can participate to forums, upload and download files, take quizzes, follow their grades and attendances.

\section{USABILITY EVALUATION}

The international standard ISO 9241-11 defines usability as "the extent to which a product can be used by specified users to achieve specified goals with effectiveness, efficiency and satisfaction in a specified context of user" (ISO, 1988). Nielsen (1993) introduced the concept of web usability by stating that making web pages simple to navigate and practical helps users in finding the 
relevant information with ease. Nielsen (1993) identified usability with the ease of use and learning and excluded functionality. Although, the ISO 924111 definition was very broad, it included functionality, computer efficiency and reliability. Bevan (2001) stated that ISO 9241-11 evaluates "usability in terms of measures of user performance and satisfaction" (p. 536). These two approaches to usability have to be combined to consider usability of MOODLE in design process. Therefore, usability in design process can be thought of as quality of design process and quality of the interaction between designer and task. There is limited amount of research on usability in architectural design process. Sagun and Demirkan (2005) developed the Evolutionary Design Collaboration Model as a web-based design environment and evaluated the user satisfaction and usability of the model related to 'perceived usefulness' and 'ease of use'. In this study, usability of the system depends upon the characteristics of the designer as well as MOODLE. Hence, the designers for achieving specific tasks in particular design environments can analyze usability in terms of the quality of use of an interactive and collaborative system.

\section{EFFECTS OF INDIVIDUAL DIFFERENCES OF LEARNERS ON THE PERCEPTION OF INFORMATION TECHNOLOGY APPLICATIONS}

Interrelationships between individual differences of learners and utilization of information technology applications in education comprise an evergrowing field of research. The present study investigates the interactions between individual characteristics of the students (such as gender, computer experience, and computer self-efficacy) and their perception of MOODLE as a communication tool for design teamwork. Although there are several conflicting results reported in the literature in this respect, many of the studies found that males had more positive computer attitudes toward information technology applications (Pektaş and Erkip, 2006; Liaw, 2002; Tsai et al. 2001; Mitra et al. 2000), had more computer experience (Pektaş and Demirbaş, 2008; Mitra et al. 2000; Shashaani, 1997), and saw themselves as more competent on computer-related tasks (i.e. had higher self-efficacy perception) (Pektaş and Demirbaş, 2008; Dickhauser and StiensmeierPelster, 2002; Whitley, 1997) than females did. Furthermore, higher levels of computer experience (Broos, 2005; Garland and Noyes, 2004) and computer self-efficacy (Abbad, Morris, and Nahlick, 2009) were associated with more positive perceptions of information technology in the literature. Thus, this study presumes that it would be interesting to evaluate the effects of such individual differences on the perception of a virtual learning environment in design teamwork.

\section{METHODOLOGY}

\section{RESEARCH SETTINGS AND PARTICIPANTS}

The research was conducted in a one-semester introductory-level obligatory CAD (Computer Aided Design) course. In this course, students acquire basic CAD skills and toward the end of the semester, they are expected to utilize these skills in a simple design project. The sample consisted of all students who took the course in one semester. A total of 42 students participated in the study. There were 28 females $(67 \%)$ and 14 males $(33 \%)$. 


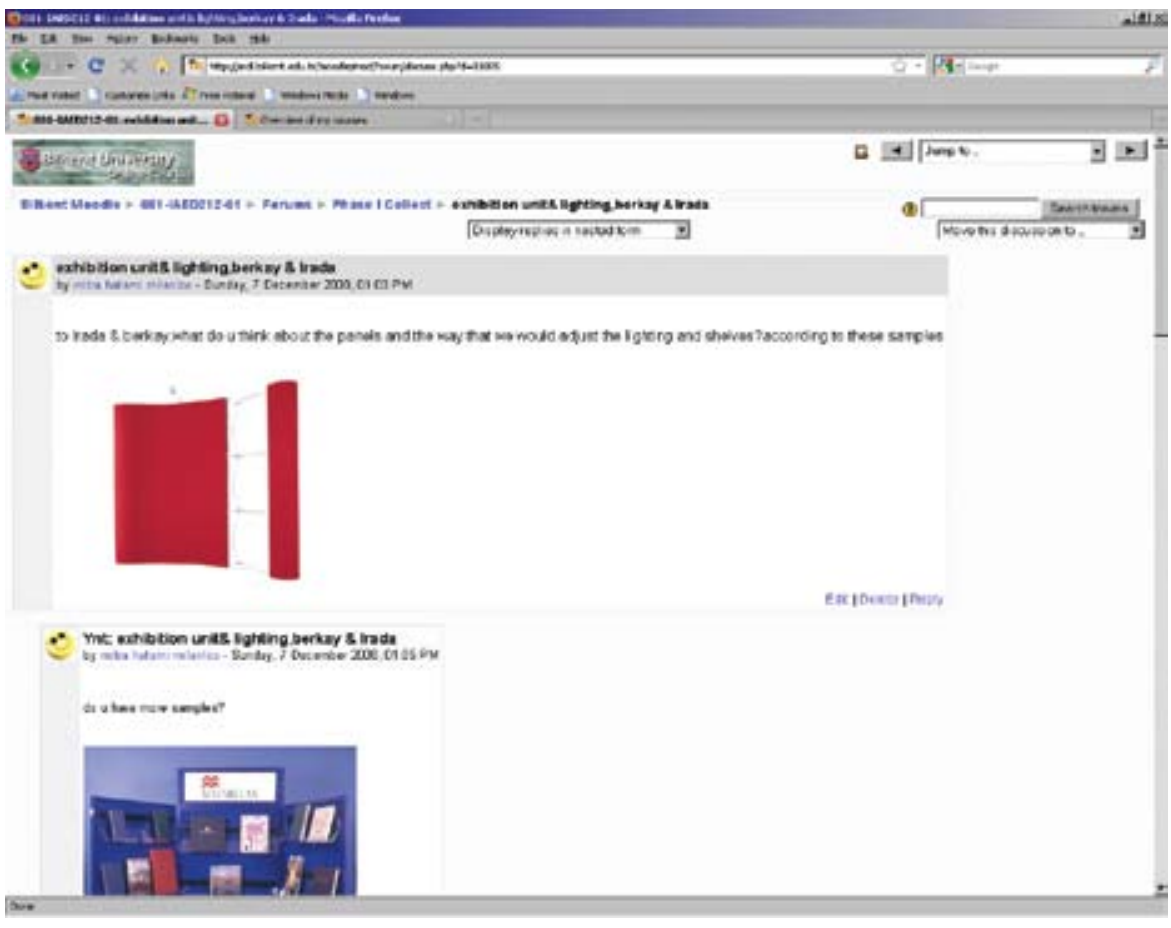

\section{PROCEDURES}

The experiment spanned the last four weeks of the semester. The students worked in groups of three and it was ensured that each group got the same instructions throughout the process. In the first week, the students received the design brief that specified the design requirements of a smallscale interior architectural design project in detail. They were asked to design a design project exhibition unit to present the works (drawings and models) of a single student in an exhibition. The unit was required to be self-standing. The students were also asked to consider how multiple units could be combined in a given space. Throughout the collaboration process, the members of groups had some defined roles, responsibilities and requirements. The students were responsible for both improving their own project with the help of critiques of other group members and making comments and giving critiques on the project of the other groups. The instructor was responsible for submitting comments and critiques through MOODLE. The same instructor conducted all of the classes in order to prevent bias.

The design project process proceeded as follows: first, the students shared some precedent examples of exhibition units and discussed them through MOODLE (Figure 2).

Then, they produced alternative designs for the project, publicized them on the MOODLE, and shared comments / critiques using MOODLE forums (Figure 3). The visual material was displayed as integrated with the textual messages, so that the students could follow the discussions easily (Figure 4). The MOODLE system allowed uploading files up to $150 \mathrm{MB}$. Thus, the resolutions of the images could be very high. 
Figure 3. Shared comments/critiques on design proposals
Figure 4. A close-up view from a discussion forum showing how the visual material was presented in integration with the text.

Figure 5. A design proposal example.

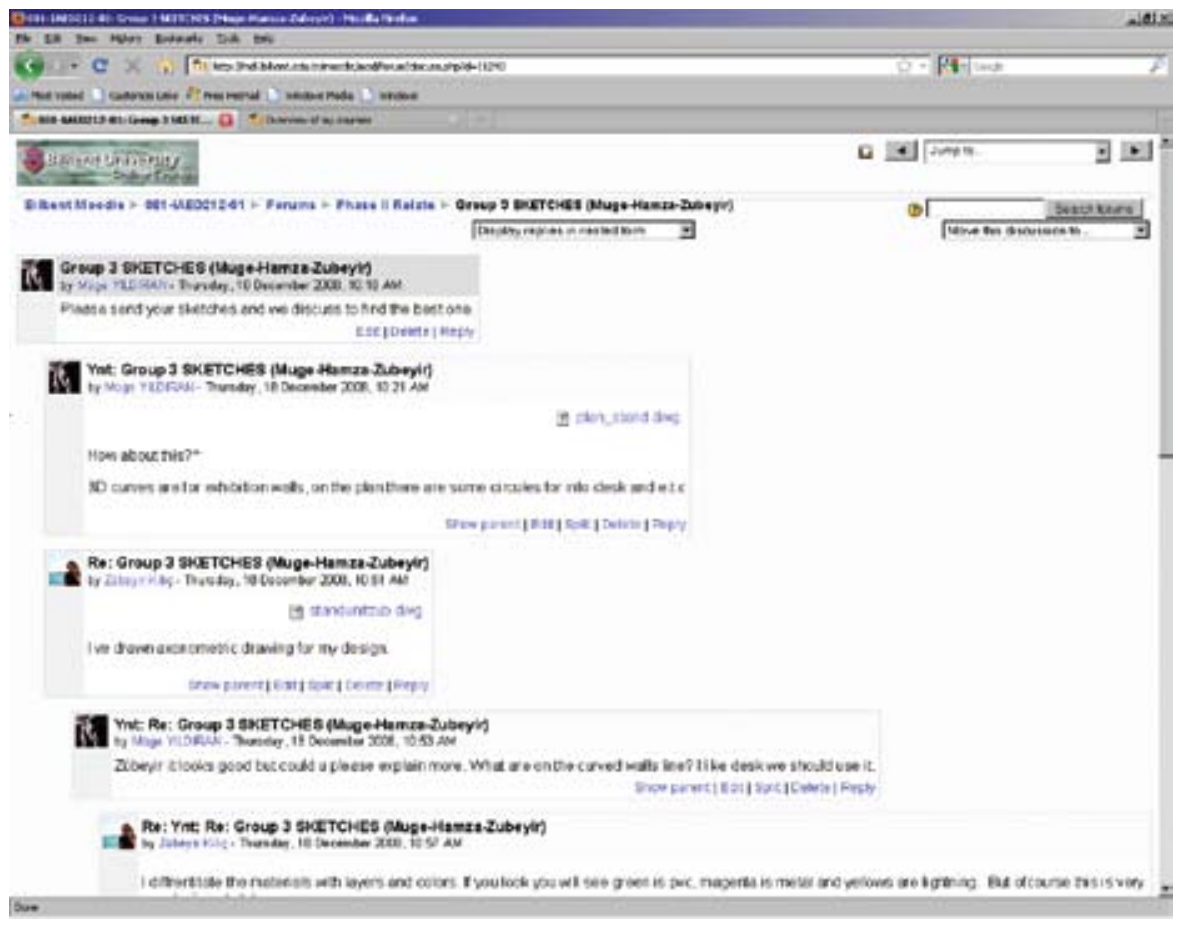

During the final week, students finalized their designs and at the end of the week, they submitted the final works (Figure 5). The survey was administered at the end of the design project in one session.

\section{MEASURES}

Perceived Usefulness and Perceived Ease of Use (PUEU) survey, which is adapted from Davis (1989), was used to investigate students' views on how easy they found MOODLE to use and how useful it is to them. Measurement of perceived usefulness explores the tendency of individuals to use a particular system or a product, in other words, the extent to which they believe it will help and enhance their job performance. The particular system or product can be useful by the users but may require too much effort to use. Thus, in addition to perceived usefulness, the perceived ease of use is also measured in PUEU to find out whether the product or system is free of effort or not. PUEU is a 12 item five-point Likert scale structured questionnaire. Responses to the statements were coded as follows: Strongly
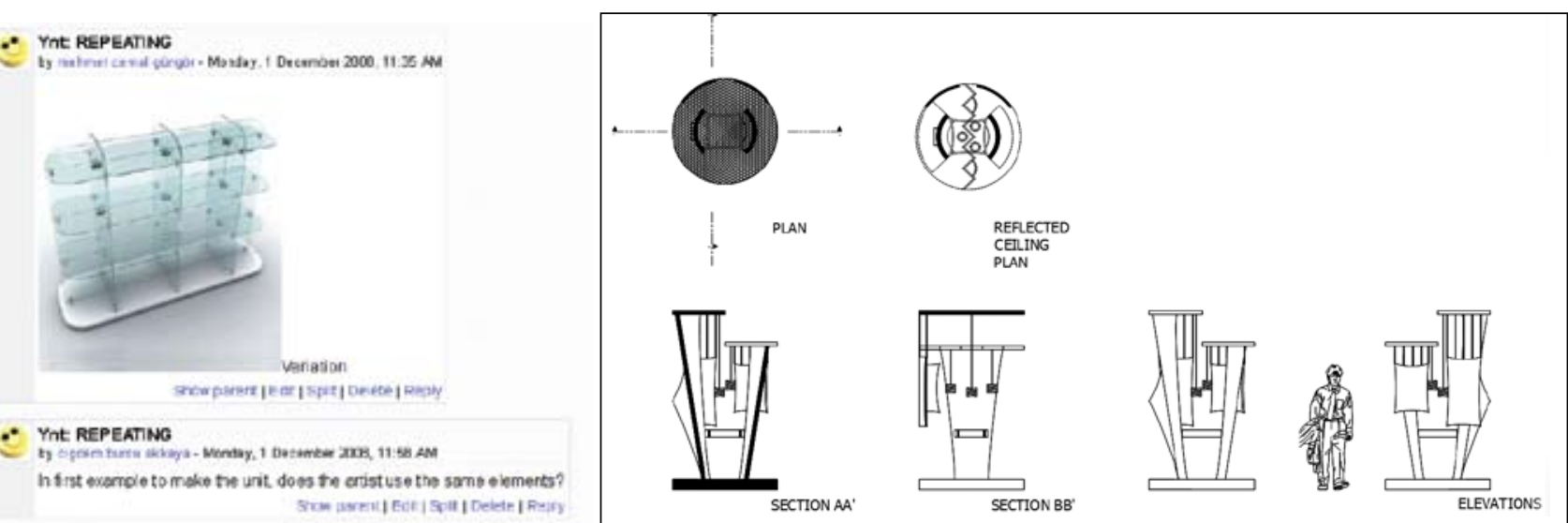
disagree $=1$, Disagree $=2$, Undecided $=3$, Agree $=4$ and Strongly agree $=5$. As a result, high scores meant positive perceptions and vice versa.

Computer experience was evaluated by specifically designed questions on this variable. Jones and Clark (1994) proposed that a thorough definition of computer experience should include its three components; namely, amount of computer use, opportunities to use computers, and diversity of computer experience. Amount of computer use refers to the period and intensity of using computers; opportunity to use computers refers to owing a computer and to having access to computers; and diversity of experience refers to the number of computer applications used. Computer experience questions were based on these dimensions and focused on the Internet use. Perceived advantages and disadvantages of MOODLE in collaborative design compared to similar traditional studio experiences were asked by open-ended questions. Gender data was also collected to examine the potential effects of gender on the other variables.

\section{ANALYSIS AND RESULTS}

Statistical analysis was applied to provide insights into the collected data. The results are presented below.

\section{Determining the factors in MOODLE use}

As an alternative approach to interpretation of the responses for each question, this study aims to view the answer to each question as information that reveals some underlying condition or factor. Therefore, the responses to the survey were subjected to Factor Analysis to identify the constructs underlying each scale for use of MOODLE. Principal Component Analysis was used to extract the relevant number of factors, and these were submitted to Varimax with Kaiser Normalization. Kaiser (1960) is the most widely used one that proposed to retain only factors with eigenvalues greater than 1 . Loadings greater than 0.50 in size were regarded as important for interpreting the factors. The items yielding salient loadings of this magnitude on each factor were taken to defined subscale. The reliability of each subscale was estimated using Cronbach's coefficient alpha.

Principal Component Analysis on the 12 items showed that 12 factors had eigenvalues greater than 1 . This analysis followed by varimax rotation resulted in 3 factors with eigenvalues greater than 1. Using factor loadings greater than \pm 0.50 , there were 3 factors after rotation with varimax with Kaiser normalization. The following findings are:

Factor 1 (eigenvalue $=6.70,32.64 \%$ of total variance) loaded on five items;

Factor 2 (eigenvalue $=1.54,28.25 \%$ of total variance) loaded on four items;

Factor 3 (eigenvalue $=1.01,16.21 \%$ of total variance) loaded on three items.

The primary factor is composed of five positively loaded items that four of them are related to perceived usefulness and one item corresponds to ease of use. The primary criterion was related to the process of design. "In architectural design process, the designer constructs a conceptual model of the artifact by abstracting knowledge from previous experiences and information stored in the memory" (Demirkan, 2005; 699). The analyses of conceptual design have revealed that drawings are an integral part among the team members. As the primary factor, it can be concluded that these drawings that are shared by the team members through MOODLE are 
Table 1. Rating scale items ranking from the highest to lowest loading in each factor thought to facilitate information processing. Use of MOODLE, provides a collaborative environment for sharing of design information, data and knowledge among the distributed design team members. Then, all the items associated with Factor 1 are related to the design process as a teamwork (Table 1).

The secondary factor is composed of four positively loaded items that are related to ease of use. All of the four items associated with Factor 2 are related to the assessment of MOODLE as a tool (Table 1). The tertiary factor is composed of three positively loaded items where two of them belong to perceived usefulness and one item belongs to ease of use. These are the items that all belong to the thoughts of the designer as a person (Table 1).

\begin{tabular}{lll}
\hline Factor & Scale & Item (loading) \\
\hline 1 & $\begin{array}{l}\text { Design process as a } \\
\text { team work (Process / } \\
\text { Task) }\end{array}$ & $\begin{array}{l}\text { Makes design easier ((0.862), enhances } \\
\text { effectiveness }(0.816), \text { flexible communication } \\
(0.754), \text { increase productivity }(0.685), \text { work } \\
\text { more quickly }(0.670)\end{array}$ \\
2 & $\begin{array}{l}\text { MOODLE as a tool } \\
\text { (Tool) }\end{array}$ & $\begin{array}{l}\text { Easy to use }(0.876), \text { controllable }(0.869), \\
\text { easy to become skilful }(0.774), \text { clear and } \\
\text { understandable }(0.740)\end{array}$ \\
3 & $\begin{array}{l}\text { Thoughts of the } \\
\text { designer (User) }\end{array}$ & $\begin{array}{l}\text { Easy to learn }(0.879), \text { improves design } \\
\text { performance }(0.700), \text { useful tool }(0.593)\end{array}$ \\
\hline
\end{tabular}

The factorial analysis suggests that a good collaborative design environment depends upon solving the dynamic interaction needs of the four principal components of a system that are identified as user, task, tool and environment (Shackel, 2009). In this situation, design process was the task that was accomplished in the collaborative environment and assessed with the highest priority. MOODLE was the tool used and was considered as the second important factor in the collaborative environment. Thoughts of the user about the in the collaborative environment was considered to be the last issue.

\section{Determining the users' perception}

Thus, the rest of the statistical analysis was based on the newly defined three factors explaining user perception in the study instead of the two factors of PUEU that were originally proposed by Davis (1989). The percentage distribution of the responses in the three groups of statements are shown in the Table 2. These findings imply that the users' perception of MOODLE as a communication tool for design teamwork was generally positive with the highest percentage of responses showing the "Agree" scale point. Only "increase productivity" item in the process dimension and "improves design performance" item in the user dimension had the highest percentage of responses in the "Disagree" scale point. 


\begin{tabular}{|c|c|c|c|c|c|c|}
\hline & & $\begin{array}{l}\text { Strongly } \\
\text { Disagree }\end{array}$ & Disagree & Undecided & Agree & $\begin{array}{l}\text { Strongly } \\
\text { Agree }\end{array}$ \\
\hline \multirow{5}{*}{ 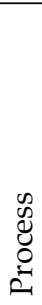 } & Makes design easier & 5 & 19 & 26 & 36 & 14 \\
\hline & Enhances effectiveness & 12 & 24 & 25 & 27 & 12 \\
\hline & Flexible communication & 7 & 7 & 37 & 34 & 15 \\
\hline & Increase productivity & 5 & 33 & 24 & 26 & 12 \\
\hline & Work more quickly & 5 & 14 & 21 & 50 & 10 \\
\hline \multirow{4}{*}{ ס } & Easy to use & 7 & 7 & 23 & 35 & 28 \\
\hline & Controllable & 7 & 9 & 19 & 36 & 29 \\
\hline & Easy to become skilful & 5 & 12 & 29 & 32 & 22 \\
\hline & Clear and understandable & 5 & 10 & 20 & 38 & 27 \\
\hline \multirow{3}{*}{$\grave{\oplus}$} & Easy to learn & 7 & 17 & 12 & 43 & 21 \\
\hline & Improves design performance & 14 & 36 & 29 & 14 & 7 \\
\hline & Useful tool & 9 & 24 & 17 & 29 & 21 \\
\hline
\end{tabular}

Table 2. Percentage distribution of the responses in the three dimensions of PUEU.
Table 3. Distribution of responses to computer experience and self-efficacy questions

\section{Relationships between individual characteristics and users' perception of MOODLE}

Finally, the relationships between individual differences of learners (gender, computer experience, and computer self-efficacy) and the use of MOODLE as a communication tool for design teamwork were investigated (Table 3).

The students were found to be highly experienced with computers and they mostly rated their skills in using a computer either as "good" or "excellent". Gender differences favoring males were found in period of using computers and in self-efficacy. The male students reported that they had been using computers for a longer period of time than the females did $(t=-2.73, p=0.01)$. Similarly, the self-efficacy scores of the male students tended to be higher than that of the females $(t=-1.95, p=0.058)$.

Pearson-r correlation analysis was applied to understand the relationships between the individual differences and the items in PUEU. Several significant negative correlations were found between the computer experience measures and the responses to the statements in the survey. This implies that as students are more experienced with computers, they have a tendency to expect more from the collaborative design tools in terms of usefulness and ease of use. Gender and self-efficacy were not found to be significantly correlated with any item in PUEU.

\begin{tabular}{llll}
\hline Questions & \multicolumn{2}{l}{ Percentage Distribution of Responses } & \\
\hline $\begin{array}{l}\text { Do you have computer at } \\
\text { home? }\end{array}$ & No $(2 \%)$ & Yes $(98 \%)$ & \\
$\begin{array}{l}\text { How long have you been } \\
\text { using computers? }\end{array}$ & Less than 3 years (2\%) & $3-7$ years (31\%) & More than 7 years (67\%) \\
$\begin{array}{l}\text { How long have you been } \\
\text { using the Internet? }\end{array}$ & Less than 3 years (9\%) & $3-7$ years (55\%) & More than 7 years (36\%) \\
$\begin{array}{l}\text { How much time do you } \\
\text { often spend on the Internet } \\
\text { in a day? }\end{array}$ & Less than 1 hour (5\%) & $1-4$ hours (69\%) & $\begin{array}{l}\text { More than } 4 \text { hours } \\
(26 \%)\end{array}$ \\
$\begin{array}{l}\text { How would you rate your } \\
\text { skills in using a computer? }\end{array}$ & Poor (5\%) & Good $(69 \%)$ & Excellent $(26 \%)$ \\
\hline
\end{tabular}




\section{Comparisons between MOODLE use in design teamwork and similar experiences in traditional studios without MOODLE}

A close inspection of the answers to the open questions revealed that MOODLE was regarded as an advantageous tool in collaborative design. The advantages of MOODLE that were perceived by the students focused on the well-established characteristics of web-based education tools such as being free of limitations of physical boundaries and of strict time schedules, sharing projects and ideas easily, and saving time. On the other hand, the main criticism of MOODLE was based on its comparison to face-toface design communication: some students complained that the design comments that they received through MOODLE might not be as expressive as those that they got through face-to-face communication.

\section{DISCUSSION AND CONCLUSION}

Results of the factorial analysis and the students' responses to the openended questions suggest that in this study, the students successfully assessed MOODLE in context with process-tool-user dimensions. The utilization of the tool in design teamwork was perceived positively and preferred to its traditional counterpart, but the study highlighted the need for some enhancements in MOODLE in order for its effective use in design education.

The design students' positive perceptions of MOODLE in this study is not surprising as Melton (2006) also pointed that MOODLE conforms to many of the conventions for usability: it has a simple interface, uses a minimal number of words, features rollovers providing extra information, and often includes simple icons with the words to aid users. These features could have been helped for the positive perceptions of the students in the case study. The findings of this study are coherent with that of Kirner, Custodio, and Kirner (2008) who concluded that the MOODLE system had a satisfactory level of usability as perceived by a group of teachers that had used it in their classes.

Although this study strongly recommends further experimentations with MOODLE in design courses, the shortcomings of the standard MOODLE system in design teamwork, as identified by the survey, seem also very interesting, because they present the opportunities for enhancements in MOODLE for its better utilization in design education. Some students expressed that communication through MOODLE might not be as intuitive as face-to-face communication and wanted to show the design change requests directly on the exchanged drawings through a more visual interface. MOODLE software has a modular structure and it is purposefully designed to be enhanced by its users (MOODLE, 2010). Thus, this study suggests that new interfaces and online redlining facilities should be integrated with MOODLE in further research.

In terms of the relationships between individual differences of learners and the perceptions of MOODLE, only a few relations were found. It seems that the widespread penetration of computers into the design fields and into the society at large in the recent years enabled design students to develop more positive perceptions of information technology applications independent from their basic individual differences such as gender, computer experience, and computer self-efficacy. 
In conclusion, the authors believe that the framework presented in this paper provides a new foundation for assessing the tools used in the collaborative design environments. The study proposes a shift from the usability point of view of collaborative environments to the assessment of the design process as well as the tool used in collaborative design process. Analyzing the collaborative environment might propose new forms of interaction between mental imaging and interaction with the collaborative design tool. The study also suggested that the effectiveness of collaborative design tools should be evaluated in their application domain contexts with the specially designed research tools. This entails that design educators themselves should be involved with design research, tool development, and analysis of results. Such an approach would facilitate for elevating the debates on digital design from a mere level of discussion to a systematic and rigorous discourse. The authors hope that this study would give rise to further studies in this track.

\section{REFERENCES}

ABBAD, M. M., MORRIS, D., NAHLICK, C. (2009) Looking under the Bonnet: Factors Affecting Student Adoption of E-learning Systems in Jordan, The International Review of Research in Open and Distance Learning, 10 (2); http:// www.irrodl.org/index.php/irrodl/article/ view/596/1218.

BEVAN, N. (2001) International Standards for HCI and Usability, International Journal of Human-Computer Studies, 55 (4) 533-52.

BROOS, A. (2005) Gender and Information and Communication Technologies (ICT) Anxiety: Male Self-Assurance and Female Hesitation, Cyberpsychology and Behaviour (8) 21-31.

DAVIS, F. D. (1989) Perceived Usefulness, Perceived Ease of Use, and User Acceptance of Information Technology, MIS Quarterly, 13 (3) 319-40.

DEDE, C., NELSON, B., KETELHUT, D.J., BOWMAN, C. (2003) DesignBased Research Strategies for Studying Situated Learning in a Multi-User Virtual Environment, in Proceedings of 6th International Conference on Learning Sciences, Santa Monica, California.

DEMIRKAN, H. (2005) Generating Design Activities through Sketches in Multi-Agent Systems, Automation in Construction,14 (6) 699-706.

DICKHAUSER, O., STIENSMEIER-PELSTER, J. (2002) Gender Differences in Computer Work: Evidence For the Model of Achievement-Related Choices, Contemporary Educational Psychology (27) 486-96.

DE LUCIA, A., FRANCESE, R.., PASSERO, I., TORTORA, G. (2009) Development and Evaluation of a Virtual Campus on Second Life: The Case of SeconDMI, Computers and Education (52) 220-33.

GARLAND, K. J., NOYES, J. M. (2004) Computer Experience: A Poor Predictor of Computer Attitudes, Computers in Human Behaviour (20) 823-40.

HAMUY, E., GALAZ, M. (2010) Information versus Communication in Course Management System Participation, Computers and Education, 54 (1) 169-77.

HOOG, J., FALKNER, C., SEIFRIED, P. (2007) Collaborative Spaces as Learning Environments: How Schools of Architecture may Find 
Their Way into the Virtual World, Em'body'ing Virtual Architecture: Proceedings of the Third International Conference of the Arab Society for Computer Aided Architectural Design, http://cumincad.scix.net/cgibin/works/Show?ascaad2007 030

INTERNATIONAL STANDARD ORGANIZATION (ISO) (1988)

Ergonomic Requirements for Office Work with Visual Display

Terminals (VDTs)- Part 11: Guidance on Usability: ISO 9241-11.

JONES, T., CLARK, V. A. (1994) A computer attitude scale for secondary students, Computers and Education (22) 315-8.

KAISER, H. F. (1960) The Application of Electronic Computers to Factor Analysis, Educational and Psychological Measurement (20) 141-51.

KARAKAYA, A. F., PEKTAŞ, Ş. T. (2007) A Framework for Webbased Education Systems Supporting Interdisciplinary Design Collaboration, METU Journal of the Faculty of Architecture, 27 (2) 13748.

KIRNER, T. G., CUSTODIO, C. A., KIRNER, C. (2008) “Usability Evaluation of the Moodle System from the Teachers' Perspective", IADIS International Conference e-Learning, available at: http://www. iadis.net/dl/final uploads/200805L048.pdf.

LIAW, S. S. (2002) An Internet Survey for Perceptions of Computers and the World Wide Web: Relationship, Prediction and Difference, Computers in Human Behaviour, 18(1): 17-35.

LIVINSTONE, D., KEMP, J. (2008) “Integrating Web-Based and 3D Learning Environments: Second Life Meets Moodle", Upgrade, v.IX, $\mathrm{n}: 3 ; 8-14$.

MARTENS, B.,ACHTEN, H. (2007) Do you Moodle? Experiences with a Virtual Learning Environment, Proceedings of the Education and Research in Computer Aided Architectural Design in Europe (ECAADE) 2007 Conference. Frankfurt/Wiesbaden, Germany, 2007; 153-60.

MELTON, J. (2006) The LMS moodle: A Usability Evaluation, Language Issues, 11-12, (1) 1-24.

MITRA, A., LENZMEIER, S., STEFFENSMEIER, T., AVON, R., QU, N., HAZEN, M. (2000). Gender and Computer Use in an Academic Institution: Report From a Longitudinal Study, Journal of Educational Computing Research, 23: 67-84.

MOODLE WEB SITE (2010) http:/ / www.moodle.org.

MOODLE-DOCS (2010) MOODLE Documents Web Site, http:/ / docs. moodle.org/en/Philosophy.

NIELSEN, J. (1993) Usability Engineering, Academic Press, London.

NOVAKOVA, K., ACHTEN, H., MATEJOVSKA, D (2010) A Design Studio Pedagogy for Experiments in Collaborative Design, Future Cities: 28th ECAADE Conference Proceedings, http://cumincad.scix.net/cgi-bin/ works/Show?ecaade2010 172.

PEKTAŞ, Ş. T., DEMİRBAŞ, Ö. O. (2008) Computer Attitudes, Learning Styles and Computer Experiences of Interior Architecture Undergraduates, Arkitekt, 518; 32-41. 
PEKTAŞ, Ş. T,. ERKİP, F. (2006) Attitudes of Design Students toward Computer Usage in Design, International Journal of Technology and Design Education, 16 (1): 79-95.

REICHL, F., HRUSKA, A. (2009) Promoting a Central Learning Management System by Encouraging Its Use for Other Purposes than Teaching, Lecture Notes in Computer Science, 5618; 689-98.

SAGUN, A., DEMİRKAN, H. (2005) Usability Evaluation of a Collaborative Web-Based Design Environment, Innovation in Architecture, Engineering and Construction, eds. S. Sariyildiz, B. Tuncer, v: 1; 253-62, Optima Grafische Communicatie, Rotterdam.

SAGUN. A., DEMIRKAN, H. (2009) On-line Critiques in Collaborative Design Studio, International Journal of Technology and Design Education, 19 (1) 79-99.

SHACKEL, B. (2009) Usability- Context, Framework, Definition, Design and Evaluation, Interacting with Computers (21) 339-46.

SHASHAANI, L. (1997) Gender Differences in Computer Attitudes and Use Among College Students, Journal of Educational Computing Research (16) 37-51.

TSAI, C. C., LIN, S .S. J., TSAI, M. J. (2001) Developing an Internet Attitude Scale for High School Students, Computers and Education, 37 (1) 41-51.

WHITLEY, B. E. (1997) Gender Differences in Computer-Related Attitudes and Behaviour: A Meta Analysis, Computers in Human Behaviour, 13 (1) 1-22.

YUEN, A., FOX, R., SUN, A., DENG, L. (2008) Student Experiences of Course Management Systems in a Hong-Kong Institution", Faculty of Education Emerging Technologies Conference 2008, http:/ / ro.uow.edu. au/etc08/25.

Alındı: 10.04.2011, Son Metin: 13.08.2011

Anahtar Sözcükler: Tasarımda işbirliği; tasarım eğitimi; MOODLE; kullanılabilirlik, kullanıcı algıları

\section{MOODLE'IN TASARIM İŞBİRLİĞİNDE BİR İLETIŞİM ARACI OLARAK KULLANILMASI: KULLANICI PERSPEKTIFINNDEN BİR ANALİZ}

Tasarım sürecinde işbirliğinin önemi yaygın olarak kabul edilmesine rağmen, tasarım eğitimi kurumlarının bu konunun öğretilmesinde birçok zorluk yaşadığı gözlemlenmektedir. Bu zorlukları aşmak için Web-tabanlı eğitim araçlarının kullanılması sıklıkla önerilmiş, fakat bu çalışmaların çoğunda kullanıcı bakış açısı ihmal edilerek konuya sadece uygulama geliştiricisi ya da öğretim elemanı perspektifinden yaklaşılmıştır. Bunun sonucunda da kullanıcıların/öğrencilerin gereksinimleri, algıları, ve deneyimleri yeterince incelenmemiştir. Belirtilen problemlerin çözümüne yardımcı olmak amacıyla, bu çalışmada öğrencilerin bir sanal öğrenme ortamı olan MOODLE'1 tasarım işbirliğinde bir iletişim aracı olarak nasıl algıladıkları incelenmektedir. MOODLE (Modular Object-Oriented Dynamic Learning Environment) pek çok disiplinde sanal öğrenme ortamı, ya da ders yönetim sistemi olarak kullanılmakta olan açık kaynak bir araçtır. Bu çalışmada, iç mimarlık öğrencilerinden oluşan bir örneklem gruplara ayrılarak, MOODLE'ı başlıca iletişim aracı olarak kullanacakları 
bir tasarım problemi verilmiştir. Daha sonra katılımcıların bu tasarım süreçlerini nasıl algıladıkları ampirik bir araştırmayla değerlendirilmiştir.

$\mathrm{Bu}$ araştırmada yanıtı aranan sorular şöyle sıralanabilir:

1. MOODLE'ın tasarım eğitiminde işbirliği için bir iletişim aracı olarak, başlıca kullanılabilirlik faktörleri nelerdir?

2. MOODLE'ın tasarım eğitiminde işbirliği için bir iletişim aracı olarak kullanılmasıyla ilgili kullanıcıların algıları nelerdir?

3. MOODLE'ın tasarım eğitiminde işbirliği için bir iletişim aracı olarak kullanılması durumunda, kullanıcı algıları ile kişisel farklılıklar (cinsiyet, bilgisayar deneyimi, ve bilgisayar becerisi algısı) arasındaki ilişkiler neler olabilir?

Öğrencilerin MOODLE'ı ne kadar kullanışlı ve kullanımı kolay olarak algıladıklarını ölçmek için Davis'in (1989) Bilgi Teknolojilerinin Algılanan Kullanışlılığı ve Kullanım Kolaylığı (Perceived Usefulness and Perceived Ease of Use, PUEU) Testi uygulanmıştır. Bilgisayar deneyimi, bu değişken için özel olarak hazırlanmış sorularla değerlendirilmiştir.

Tasarım işbirliğinde MOODLE kullanımı ile ilgili faktörleri ortaya çıkarmak için Principal Component Analysis uygulanmış ve Kaiser Normalizasyonu ile Varimax yöntemleri ile döndürülmüş temel bileşenler analizi yapılmıştır. Analiz sonucunda MOODLE kullanımında öğrencilerin alg1sı konusunda üç ana faktör olduğu ortaya çıkmıştır. Bunlar: tasarım süreci, MOODLE'ın bir araç olarak değerlendirilmesi ve kişi olarak tasarımcı faktörüdür.

Faktöriyel Analiz iyi bir işbirlikçi tasarım ortamının sistemin kullanıcı, süreç, araç, ve çevre olarak tanımlanan dört ana bileşeni arasındaki dinamik etkileşimlerin çözümüne bağlı olduğunu ortaya koymuştur. Bu durumda tasarım süreci en büyük önceliğe sahip faktör olarak öne çıkmaktadır. Bir araç olarak MOODLE katılımcılar tarafından ikinci önceliğe sahip faktör olarak değerlendirilmiştir. Kullanıcının işbirlikçi ortam hakkındaki düşünceleri ise sonuncu faktör olarak ortaya çıkmıştır.

Açık uçlu sorulara verilen yanıtların incelenmesi, MOODLE'ın işbirlikçi tasarımda avantajı bir araç olarak değerlendirildiğini ortaya koymuştur. Fakat, MOODLE'ın bu bağlamda bazı dezavantajları da öğrenciler tarafından dile getirilmiştir. Son olarak, öğrencilerin kişisel farklılıkları (cinsiyet, bilgisayar deneyimi ve bilgisayar becerisi algisı) ile MOODLE'1 algılamaları arasındaki ilişkiler incelenmiştir. Bilgisayar deneyimi ile bahsedilen yanıtlar arasında çeşitli negatif korelasyonlar bulunmuştur. Bu göstermektedir ki, öğrenciler bilgisayar konusunda deneyimli oldukça işbirlikçi tasarım araçlarından kullanılabilirlik ve kullanım kolaylığı anlamında beklentileri de artmaktadır.

Öğrencilerin bilgisayar konusundaki deneyimli profilleri, bilgisayar deneyimi ile PUEU'daki ifadeler arasındaki negatif korelasyonlar, ve öğrencilerin açık uçlu sorulara verdikleri yanıtların incelenmesi sonucu, bu çalışmada katılımcıların MOODLE'ı son derece başarılı bir şekilde kullanım bağlamında ve süreç-araç-kullanıcı boyutlarıyla birlikte değerlendirdikleri görülmüştür. Bu aracın, tasarım ekip çalışmasında kullanımı olumlu karşılanmış ve geleneksel tasarım stüdyosundaki benzer uygulamalara tercih edilmiştir. Bununla birlikte, bu çalışma MOODLE'ın tasarım eğitiminde etkin bir şekilde kullanılabilmesi için gereksinim duyduğu bazı iyileştirmeleri de ortaya çıkarmıştır. 
Sonuç olarak, yazarlar bu makalede sunulan çerçevenin işbirlikçi tasarım araçlarının değerlendirilmesinde yeni bir temel oluşturacağına inanmaktadır. Bu çalışma işbirlikçi ortamların değerlendirilmesinde kullanılabilirliğin yanı sıra, sürecin de önemine işaret etmektedir. Bu çerçeve içinde benzer çalışmalarda işbirlikçi ortamların incelenmesi tasarımcının zihinsel modellemesi ile işbirlikçi tasarım araçları arasında yeni etkileşimler ortaya çıkarabilir. Bu çalışma ayrıca, işbirlikçi tasarım araçlarının etkinliklerinin kendi uygulama alanları içinde ve bu uygulamalara özel araştırma araçlarıyla incelenmesi gerektiğini ortaya koymuştur. Bu da, tasarım eğitmenlerinin bizzat kendilerinin tasarım araştırmaları, araç geliştirme, ve uygulama sonuçlarının analiziyle ilgilenmesini gerektirmektedir. Böyle bir yaklaşım, mimarlık eğitiminde sayısal tasarım tartışmalarını basit bir seviyeden sistematik ve ciddi bir akademik söyleme dönüştürmeye yardımcı olacaktır. Sunduğumuz çalışmanın bu bağlamda benzer çalışmalara yön vermesi umulmaktadır.

ŞULE TAŞLI PEKTAŞ; B.Arch, M.F.A, Ph.D.

Received B.Arch (1997) from METU, M.F.A (1999) and Ph.D. (2003) degrees from Bilkent University, where she currently teaches. Was a visiting scholar at Cambridge University, Engineering Design Centre, UK. Areas of interest include design methods, Computer Aided Architectural Design (CAAD) and CAAD education.

HALIME DEMİKAN; B.S., M.S., Ph.D.

Received B.S. (1978) and M.S. (1981) in Industrial Engineering and Ph.D. (1989) in Architecture from METU. Currently working as professor in the Interior Architecture and Environmental Design Department at Bilkent University. Areas of interest are creativity in architectural design process, design education and human factors in computer-aided design. 
